\title{
Interpreting a Radical Prostatectomy Report
}

\author{
Radikal Prostatektomi Raporunun Yorumlanması
}

\author{
(D) Yasemin Yuyucu Karabulut \\ Mersin University, Department of Pathology, Mersin, Turkiye
}

\begin{abstract}
Worldwide, clinically detected prostate cancer is the second most common malignancy, with an estimated 1.1 million new cases in 2012 . Standard active treatments for prostate cancer include radiotherapy and/or radical prostatectomy (RP) (for clinically localized prostate cancer). Also active surveillance is a management strategy to avoid or delay the potential harms caused by radical treatments. At this point, a pathology report plays a major role. Appropriate handling and systematic examination of a RP specimen is essential for the identification of tumor characteristics such as grade, volume, pathological stage, and surgical margin status. Although some minor differences in macroscobic evaluation may be seen among authors, it is essential to paint and sample the entire prostatectomy specimen. Most prostate tumors are heterogeneous and multifocal compared to tumors of other organs. This makes macroscopic assessment of prostatectomy specimen challenging and sampling of a representative material from the main tumor focus difficult. Also determining tumor burden and to interpret all surgical margins total sampling of the material is essential. Keywords: Extraprostatik extansion, Intraprostatic insicion, Positive surgical margin
\end{abstract}

\section{Öz}

Dünyada, klinik olarak tespit edilen prostat kanseri, 2012'de tahmin edilen 1,1 milyon yeni olguyla en sık görülen ikinci malignitedir. Prostat kanseri için standart aktif tedaviler arasında radyoterapi ve/veya radikal prostatektomi (klinik olarak lokalize prostat kanseri için) bulunur. Ayrıca aktif izlem, diğer tedavilerin neden olduğu olası zararları önlemek veya geciktirmek için uygun hastalarda alternatif bir tedavi yöntemidir. Bu noktada patoloji raporu önemli rol oynar. Radikal prostatektomi materyalinin uygun makroskobik incelemesi ve örneklenmesi son derece önemlidir. Otörler arasında bazı küçük farklılıklar görünse de, prostatektomi materyalini boyamak ve total örneklemek gerekir. Ayrıca tümör yükünün belirlenmesi ve tüm cerrahi sınırların yorumlanabilmesi için totale yakın örnekleme önemlidir.

Anahtar Kelimeler: Ekstraprostatik yayılım, İntraprostatik insizyon, Pozitif cerrahi sınır

\section{Introduction}

\section{Interpreting a Radical Prostatectomy Report}

Clinically diagnosed prostate cancer was the second most common malignancy in the world in 2012 (1). Radiotherapy and, for clinically localized form, radical prostatectomy (RP) are standard active treatments for prostate cancer. In addition, active surveillance is a management strategy in appropriate patients to prevent or delay the potential harm caused by radical treatments.

At this point, pathology report plays a major role. Appropriate handling and systematic examination of a RP specimen is essential for the identification of tumor characteristics such as grade, volume, pathological stage, and surgical margin status. Although some minor differences in macroscobic evaluation may be seen among authors, it is essential to paint and sample the entire prostatectomy specimen. Most prostate tumors are heterogeneous and multifocal compared to tumors of other organs. This complicates the macroscopic evaluation of the tumor.

Determining tumor burden and interpreting all surgical margins total sampling of the material is essential.

The eighth edition of the American Joint Committee on Cancer (AJCC) cancer staging manual (8E AJCC) includes some changes in staging prostate cancer (2). To briefly summarize, there is no pT1 category for RP specimens anymore. Several retrospective

Correspondence: Yasemin Yuyucu Karabulut MD, Mersin University, Department of Pathology, Mersin, Turkiye Phone: +90 5056497196 E-mail: yykarabulut@yahoo.com.tr ORCID-ID: orcid.org/0000-0001-6619-6868 Received: 30.01 .2019 Accepted: 14.02 .2019

Cite this article as: Karabulut YY. Interpreting a Radical Prostatectomy Report. J Urol Surg 2019;6(2):168-171 
outcome data analyses subdividing pT2 disease into three categories as pT2a, pT2b, and pT2c have no prognostic value. No data exist to allow correlation of pT2 stage subgrouping with survival in localized prostate cancer due to the indolent and prolonged clinical course of the disease. In the 8E AJCC TNM staging manual, $\mathrm{PT} 3$ disease is subdivided into two categories as pT3a and pT3b, evaluating the presence of extraprostatic extension (EPE) and the presence of seminal vesical invasion with or without EPE. In the $8 \mathrm{E} \mathrm{AJCC}$, microscopic bladder neck invasion is considered as pT3a, similar to the old version (2).

Periseminal vesicle soft tissue invasion, staged as pT3a (EPE), should be distinguished from seminal vesicle invasion (pT3b) that keeps the tumor cells in the muscular wall of the seminal vesicle. In the revised form, there is no change for staging $L N$ metastasis in prostate cancer. Tumor that is fixed or invades adjacent structures other than seminal vesicles, such as rectum, bladder, levator muscles or pelvic wall, is categorized as pT4 (Table 1) $(2,3)$.

The International Society of Urological Pathology (ISUP) consensus conference held in March 2009 in Boston made recommendations for standardization of pathology reporting of RP samples. The results of the meeting are presented in five subsequent workgroup reports (4).

In fact, this is not a pure pathology text to elaborate staging. Pathology reports play a major role in the implementation of new treatment modalities. As known, pathology is a rapidly changing and developing science, and there are many parameters in a prostatectomy report which must be interpreted by urologists.

In order to understand the messages given in a pathology report, the urologist and the pathologist should speak the same language. The goal of this review is to provide information for urologists to take all messages given by the pathologist in a RP report.

EPE (focally or extensively), intraprostatic incision (IPI), surgical margin positivity (PSM) in the presence of IPI, and PSM in the presence of EPE are the parameters which are commonly used in RP reports besides the identification of tumor characteristics

Table 1 . Summary of the $8^{\text {th }}$ tumor-node-metastasis staging changes of prostat

pT2 No longer subcategorized based on bilaterality and extent of involvement

pT3 Divided into two categories; -pT3a: the presence of extraprostatic extension in any location -pT3b: presence of seminal vesical invasion with or without extraprostatic extension

pT4 Tumor is fixed or invades adjacent structures other than seminal vesicles, such as rectum, bladder, levator muscles or pelvic wall such as grade, volume, pathological stage, and surgical margin status.

Here, we briefly summarize these parameters;

Extraprostatic extension: TNM staging system for prostate cancer defines pT3a as extension of tumor into periprostatic soft tissue. The terms of capsular penetration and capsular invasion are not recommended to be used anymore, because the prostate has not got a true histological capsule. Therefore, EP is the preferred terminology $(5,6)$. In fact, there is limited data to assess interobserver agreement between pathologists in the evaluation of EPE. Two separate studies on this subject have shown a significant variability between experienced pathologists and non-specialists $(7,8)$.

The most easily recognizable sign EPE is determining tumor cells in periprostatic fat. In fact, it varies according to different regions of the prostate; EPE is most commonly identified in the posterolateral part of the gland, because the tendency of perineural spread of the prostate tumor is considered as the basic extraprostatic spreading mechanism (9). A bulging tumor nodule beyond the normal contour of the gland can also be recognized as EPE (9).

Tumors detected in apex/distal border sections are not considered extraprostatic spread because benign glands can often be found within the striated muscle, as a result of which the malignant glands in the striated muscle cannot be considered an extraprostatic spread $(7,8)$.

The extent of EPE should be mentioned in a pathology report, because radial distance of EPE is the only independent predictor of PSA failure recurrence in multivariate analysis (10). Therefore, assessing the EPE, the terms "focally" and "extensively" are recommended to be used in the reports $(1,11,12)$. Focally means, a few neoplastic glands just outside the prostate or extraprostatic tumor occupying less than one high-power field in no more than two sections, and extensively means more than focal $(11,12)$.

Of course PSM should be indicated separately in the EPE focus (Figure 1,2).

Intraprostatic Insicion means that the surgeon was unable to remove the entire prostate and some of the prostate tissue remained in the patient. IPI has a significant negative impact on patient outcome following $\operatorname{RP}(13,14,15,16,17,18)$. The urologist should know that there may be no biochemical remission in the presence of IPI. PSM may occur as a consequence of IPI so the pathologists must specify if there is a tumor on focus of IPI (Figure 3,4 ), because it is associated with decreased biochemical recurrence-free survival $(19,20)$. 


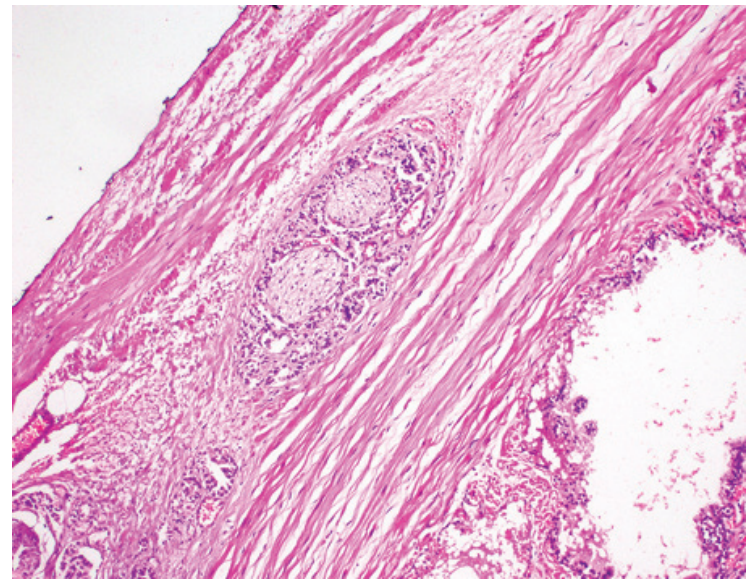

Figure 1. Tumor cells surrounding the nerves in the periprostatic area means, extraprostatic extension (h\&e; x100)

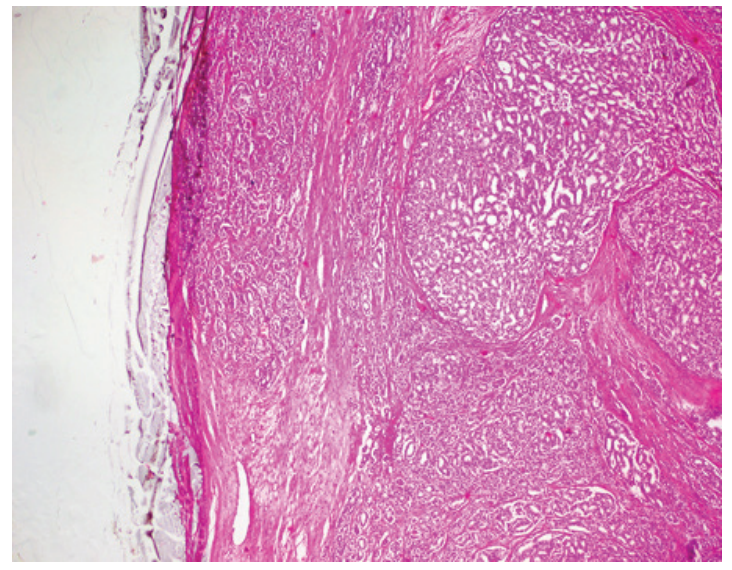

Figure 2. Surgical margin positivity in the focus of extraprostatic extension (h\&e; $x 40)$

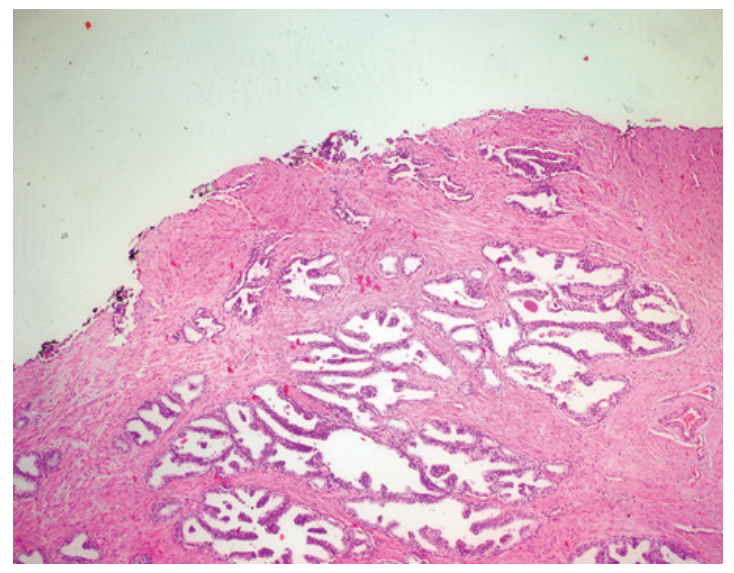

Figure 3. Benign prostat glands in surgical margin of the prostatectomy material means, intraprostatic incision (h\&e; $x 40)$

Also it is recommended determine Gleason score of tumor at the PSM focus (19).

Bladder neck invasion was designated as pT4 disease in the 2002 AJCC TNM staging system, whereas, microscopic bladder neck invasion was categorized as pT3a cancer in the 2009 TNM (21).

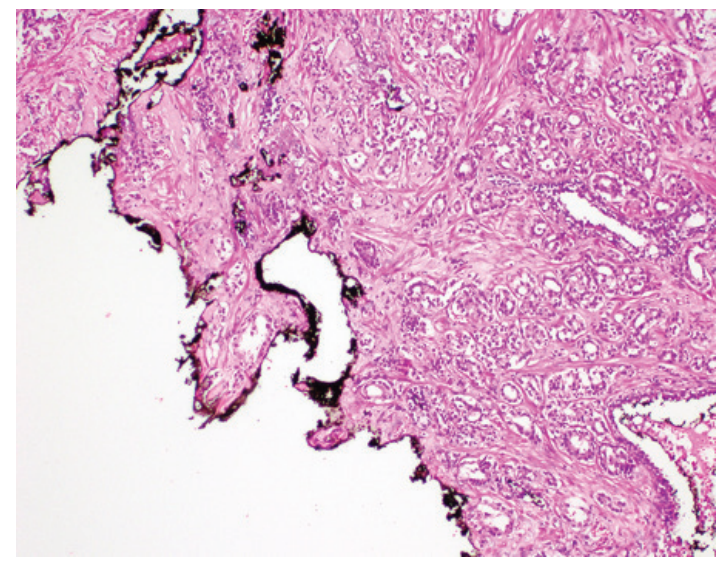

Figure 4. Surgical margin positivity in the focus of intraprostatic incision (h\&e; x40)

The results of ISUP consensus meeting on microscopic bladder neck invasion revealed that tumor involving the bladder neck specifically defined as neoplastic cells within thick smooth muscle bundles, should be reported as pT3a. For categorization as pT4, gross invasion of the bladder neck is required. In the presence of malignant glands intermixed with benign glands in the bladder neck, this should be considered equivalent to the IPI; if tumor is present at the inked resection margin at the bladder neck, this should be stated in the pathology report $(10,22,23)$.

In fact, there are controversies as to whether microscopic bladder neck invasion is an independent histological prognostic parameter.

In multivariate models, bladder neck invasion was found not to be an independent predictor of PSA failure recurrence after RP, and prognosis was dependent on other pathological features (24). The importance of microscopic bladder neck invasion has not been clarified yet. Nowadays there are new studies going on for this topic.

\section{Conclusion}

As mentioned before, this is not a pure pathology text to elaborate staging. Therefore, it has been prepared without detailing the pathology to draw attention of the clinician to some newly defined parameters. Thus, pathologists may not find more details in this text.

When evaluating a pathology report, urologists should be able to interpret the details given in the report without looking for the term "capsule invasion" anymore.

\section{Ethics}

Peer-review: Internally peer-reviewed.

Conflict of Interest: No conflict of interest was declared by the authors. 
Financial Disclosure: None.

\section{References}

1. Moch $H$, Humphrey PA, Ulbright TM, Reuter VE. WHO Classification of Tumours of the Urinary System and Male Genital Organs. Geneva, Switzerland: WHO Press; 2016.

2. Amin $M B$, Edge $S$, Greene $F$, Byrd DR, Brookland RK, Washington MK, Gershenwald JE, Compton CC, Hess KR, Sullivan DC, Jessup JM, Brierley JD, Gaspar LE, Schilsky RL, Balch CM, Winchester DP, Asare EA, Madera M, Gres, DM, Meyer LR. AJCC Cancer Staging Manual. Ed. 8 Cham, Switzerland: Springer; 2017.

3. Karabulut YY. Summary of the Changes in the 8th Edition of the TumorNode- Metastasis Staging of Urological and Male Genital Organs Cancers. Journal of Urological Surgery 2018;5(2):133-139.

4. Egevad L, Srigley JR and Delahunt B. International Society of Urological Pathology (ISUP) Consensus Conference on Handling and Staging of Radical Prostatectomy Specimens: rationale and organization. Modern Pathology (2011) 24,1-5.

5. Srigley JR, Amin MB, Epstein Jl, et al. Updated protocol for the examination of specimens from patients with carcinomas of the prostate gland. Arch Pathol Lab Med 2006;130:936-946.

6. Srigley JR. Key issues in handling and reporting radical prostatectomy specimens. Arch Pathol Lab. Med 2006;130:303-317.

7. Cristina Magi-Galluzzi, Andrew J Evans, Brett Delahunt, Jonathan I Epstein at al. International Society of Urological Pathology (ISUP) Consensus Conference on Handling and Staging of Radical Prostatectomy Specimens. Working group 3: extraprostatic extension, lymphovascular invasion and locally advanced disease. Modern Pathology (2011) 24,26-38.

8. Ekici $\mathrm{S}$, Ayhan $A$, Erkan I, et al. The role of the pathologist in the evaluation of radical prostatectomy specimens. Scand J Urol Nephrol 2003;37:387391.

9. Villers $A, M c N e a l J E$, Redwine $E A$, et al. The role of perineural space invasion in the local spread of prostatic adenocarcinoma. J Urol 1989;142:763-768.

10. Galluzzi M, Evans AJ, Delahunt B, Epstein JI, Griffiths DF, Kwast T, Montironi R, Thomas M, Srigley J, Egevad L, Humphrey P; The ISUP Prostate Cancer Group. International Society of Urological Pathology (ISUP) Consensus Conference on Handling and Staging of Radical Prostatectomy Specimens. Working group 3: extraprostatic extension, lymphovascular invasion and locally advanced disease. Modern Pathology (2011) 24,26-38.
11. Epstein Jl, Carmichael MJ, Pizov G, et al. Influence of capsular penetration on progression following radical prostatectomy: a study of 196 cases with long-term follow-up. J Urol 1993;150:135-141.

12. Wheeler TM, Dillioglugil 0, Kattan MW, et al. Clinicaland pathological significance of the level and extent ofcapsular invasion in clinical stage T1-2 prostate cancer. Hum Pathol 1998;29:856-862.

13. Van der Kwast TH, Collette L, Van Poppel H, et al.Impact of pathology review of stage and margin status of radical prostatectomy specimens. Virchows Arch 2006;449:428-434.

14. Wieder JA, Soloway MS. Incidence, etiology, location, prevention and treatment of positive surgical margins after radical prostatectomy for prostate cancer. J Urol 1998;160:299-315.

15. Preston MA, Carrière $M$, Raju $G$, et al. The prognostic significance of capsular incision into tumor during radical prostatectomy. Eur Urol 2011;59:613-8.

16. Shuford MD, Cookson MS, Chang SS, et al. Adverse prognostic significance of capsular incision with radical retropubic prostatectomy. J Urol 2004; 172:119-23.

17. Chalfin HJ, Dinizo $M$, Trock BJ, et al. Impact of surgical margin status on prostate-cancer-specific mortality. BJU Int 2012; 110:1684-9.

18. Epstein Jl. Incidence and significance of positive margins in radical prostatectomy specimens. Urol Clin North Am 1996; 23:651-63.

19. Park SW, Readal N, Ceong BC, at al. Risk Factors for Intraprostatic Incision into Malignant Glands at Radical Prostatectomy. Eur Urol 2015;68:311-316.

20. Freedland SJ, Grubb KA, Yiu SK, et al. Obesity and capsular incision at the time of open retropubic radical prostatectomy. J Urol 2005;174:1798-801.

21. Edge SB, Byrd DR, Carducci M, et al. AJCC Cancer Staging Manual 7th edn. Springer: New York, NY, 2009.)

22. Rodriguez-Covarrubias F, Larre $S$, Dahan $M$, et al. Invasion of bladder neck after radical prostatectomy: one definition for different outcomes. Prostate Cancer Prostatic Dis 2008;11:294-297.

23. Buschemeyer 3rd WC, Hamilton RJ, Aronson WJ, et al. Is a positive bladder neck margin truly a T4 lesion in the prostate specific antigen era? Results from the SEARCH Database. J Urol 2008;179:124-129.

24. Dash $A$, Sanda MG, Yu M, et al. Prostate cancer involving the bladder neck: recurrence-free survival and implications for AJCC staging modification. American Joint Committee on Cancer. Urology 2002; 60:276-280. 